\title{
Climate change and youth unemployment challenges in Nigeria: The poultry production option
}

Ahiwe, E. U., Obikaonu, H. O., Kadurumba, O. E., Iwuji, T. C., Emenalom, O. O. and Etuk, E. B.

Department of Animal Science and Technology

Federal University of Technology,

P.M.B 1526, Owerri

Abstract Corresponding author: emmanuel.ahiwe@futo.edu.ng

This paper discusses climate change and poultry production as their interaction impacts on unemployment in Nigeria. Climate change and animal production have always had a negative impact on each other, with animal production accounting for about 15-18\% global anthropogenic greenhouse gases (GHGs) emission in form of carbon dioxide $\left(\mathrm{CO}_{2}\right)$, nitrous oxide $\left(\mathrm{N}_{2} \mathrm{O}\right)$ and methane $\left(\mathrm{CH}_{4}\right)$ which are emitted when animals respire. On the other hand, the effect of climate change and global warming on animal production is on the increase and will continue to increase with the high rate of man's industrial activity if not checked. In Nigeria, there is an increasing demand for animal protein and the unemployment rate is increasing yearly because of high increase in population. In order to meet up with this increase in demand for food and reduce youth unemployment in an environment with less climate change challenge, more youth involvement in Agriculture is needed. But, this agricultural revolution will have great challenge on the environment because of the high rate of climate change that goes with industrialization and agriculture. Because poultry have low global warming potential, it has an edge over other animals or livestock such as cattle, sheep, and goat. This is because poultry has low GHGs emission as a result of its low enteric methane production rates compared to ruminant animal species. Apart from poultry being cheap, it is nutritious and readily marketable. In addition, it can be a nice source of investment and income generation for Nigerian youths, if harnessed properly. It is therefore, concluded and recommended that to meet up with the ever-increasing demand for jobs in an environment having less climate change challenges, various government agencies, banks, private sectors, civil society, rural co-operative societies, youth agencies in Nigeria with the assistance of various international donor agencies can collaborate and play a more facilitating role through giving of loans, grants and adequate extension services to ensure that food security and youth empowerment is achieved within an eco-friendly environment through profitable poultry production.

Keywords: Poultry production, youth unemployment, climate change, Nigeria.

\section{Changement climatique et défis du chômage des jeunes au Nigéria: L'option de production avicole}

\section{Résumé}

Cet article discute du changement climatique et de la production de volaille comme leurs effets d'interaction sur le chômage au Nigéria. Le changement climatique et la production animale ont toujours eu un impact négatifl'un sur l'autre, la production animale représentant environ 15 à 18\% des émissions mondiales de gaz à effet de serre (GES) anthropiques sous forme de dioxyde de carbone (CO2), d'oxyde nitreux (N2O) et de méthane (CH4) qui sont émis lorsque les animaux respirent. En revanche, l'effet du changement climatique et du réchauffement planétaire sur la production animale est en augmentation et continuera d'augmenter avec le taux élevé de l'activité industrielle de l'homme s'il n'est pas maîtrisé. Au 


\section{Climate change and youth unemployment challenges in Nigeria}

Nigéria, il y a une demande croissante de protéines animales et le taux de chômage augmente chaque année en raison de la forte augmentation de la population. Afin de répondre à cette augmentation de la demande alimentaire et de réduire le chômage des jeunes dans un environnement où les défis du changement climatique sont moins importants, une plus grande implication des jeunes dans l'agriculture est nécessaire. Mais, cette révolution agricole aura un grand défi sur l'environnement en raison du taux élevé de changement climatique qui accompagne l'industrialisation et l'agriculture. Parce que la volaille a un faible potentiel de réchauffement planétaire, elle a un avantage sur les autres animaux ou le bétail comme les bovins, les moutons et les chèvres. En effet, la volaille a de faibles émissions de GES en raison de ses faibles taux de production de méthane entérique par rapport aux espèces animales ruminantes. En plus d'être bon marché, la volaille est nutritive et facilement commercialisable. En outre, il peut être une belle source d'investissement et de génération de revenus pour les jeunes Nigérians, s'il est correctement exploité. Il est donc conclu et recommandé que pour répondre à la demande toujours croissante d'emplois dans un environnement ayant moins de défis liés au changement climatique, diverses agences gouvernementales, banques, secteurs privés, société civile, sociétés coopératives rurales, agences de jeunesse au Nigéria avec l'aide de divers organismes donateurs internationaux peuvent collaborer et jouer un rôle plus facilitateur en accordant des prêts, des subventions et des services de vulgarisation adéquats pour garantir la sécurité alimentaire et l'autonomisation des jeunes dans un environnement respectueux de l'environnement grâce à une production avicole rentable.

Mots clés: Production volaille, chômage des jeunes, changement climatique, Nigéria.

\section{Introduction}

For many decades, climate change has been one of the environmental issues the global community has been facing. Humans, animals and their environment have been affected by climate change. Understanding and getting a better knowledge of this global challenge is important. Climate change is a periodic modification of earth's climate occasioned by variability in the atmosphere as well as interactions between the atmosphere and other geologic, chemical, biological, and geographic factors within the earth system (Jackson, 2021). It can also be described as a change in the pattern of weather (including precipitation, temperature, and wind patterns), and related changes in oceans, land surfaces and ice sheets, occurring over time scales of decades or longer (Australian Academy of Science, 2021). Generally, there is an increasing concern on the negative effect of climate change and Nigeria is not left out.
From a global perspective, according to Niang and Nyong (2007) the effects of climate change vary from region to region. Climate change ordinarily should occur naturally at a gradual pace, but as a result of several factors, the rate of climate change has continued to increase unabated. It is the fast rate and the extent at which climate change occurs in recent times that provokes immense concern globally (Niang and Nyong, 2007; FAO, 2020). With expanding worldwide surface temperatures, the chances of more drought occurrence are high (Cook, 2018). More heat in the atmosphere and warmer ocean surface temperatures can lead to increased wind speeds in tropical storms (Berardelli, 2019). In addition, as water vapour goes continuously into the environment it becomes fuel for all the more remarkable storms to form and occur (Berardelli, 2019). Furthermore, it is noticed that rising sea levels tends to expose higher locations that are not usually subjected to the power of the 


\section{Ahiwe, Obikaonu, Kadurnmba, Iwuji, Emenalom and Etuk}

sea to the erosive forces of sea currents and sea waves. In Nigeria, the occurrence of climate change can be seen in the continuous rise in temperature, variable rain fall, increased flooding, erosion and droughts in different regions of the country (Shiru et al., 2020). Climate change occurs as a result of natural changes as well as anthropogenic (human-induced) factors (Trenberth, 2018). Anthropogenic induced climate change could be as a result of industrial activities such as burning of coal, oil and gas flaring, waste disposal, transportation and agricultural activities such as livestock and poultry production, deforestation, bush burning, tillage practices, etc. These human activities tend to increase methane, carbon dioxide and nitrous oxide concentrations in the atmosphere. With the increasing interest in Agriculture and animal production in particular as a source of livelihood and employment in Nigeria, there is the danger of exacerbating the negative effect of climate change issues in the country. As reported by FAO, 2020, agriculture accounts for around $21-25 \%, 42 \%$ and $72 \%$ of total human induced emissions of carbon dioxide $\left(\mathrm{CO}_{2}\right)$, methane $\left(\mathrm{CH}_{4}\right)$ and nitrous oxide $\left(\mathrm{N}_{2} \mathrm{O}\right)$, respectively. Studies have shown that livestock contributes immensely to global warming which leads to climate change (Isserman, 1992; Duxbary and Mosier, 1993; Yahya, 2019). According to Sejian (2016) and FAO (2020), the animal agriculture sector is responsible for approximately $15-18 \%$ or nearly one-fifth of human induced greenhouse gas (GHG) emissions. In nearly every step of meat, egg, and milk production, climate changing gases are released into the atmosphere potentially disrupting weather, temperature and ecosystem health (FAO, 2006, Sejian et al, 2016). Apart from climate change, another challenge that is of great concern in Nigeria is the issue of youth unemployment. For several decades, Nigerian population has been on the increase and there is a corresponding increase in the Nigerian youth population (Etebong, 2018). Presently, there is less jobs available for the ever increasing Nigerian youth population that is willing to work. This is indeed a great concern for the future of the nation (Gbosi, 2006; National Bureau of Statistics, 2020). Though for several decades, the Nigerian government and other stakeholders have been working hard to create more jobs, skill acquisition programs and youth empowerment schemes to curb or reduce youth unemployment (Onuba, 2020). But a lot still needs to be done. In most countries globally (including Nigeria), most job creation activities are not eco-friendly thus contributing to climate change challenges. There is need therefore to source for a youth empowerment or job creation scheme that will curb Nigerian youth unemployment within an eco-friendly environment with minimal climate change emission. One of such option is poultry production. Different animals have different GHG emission rate. Poultry emits the least GHG of $8 \%$ compared to other farm animals such as beef cattle $(41 \%)$, dairy cattle $(20 \%)$, goat (12\%), and pig (9\%) (Rojas-Downing et al., 2017). Published literatures (Costa, 2009; Gerber et al., 2013; Rojas-Downing et al., 2017) indicates that that poultry has one of the least GHG emission hence making it a good choice of agricultural enterprise where youths could be empowered and employed in Nigeria. This article discusses the possible adoption of poultry production as an option in reducing climate change and youth unemployment in Nigeria.

\section{Climate change and its causes}

As explained indicated in the introductory section of this discuss, climate change is a variation in the pattern of weather including precipitation, temperature, and wind patterns and related changes in oceans, land surfaces and ice sheets, occurring over time (Australian Academy of Science, 2021 and 


\section{Climate change and youth unemployment challenges in Nigeria}

Jackson 2021). Climate change has always happened on Earth, but it is the rapid rate and the magnitude of climate change occurring now that is of great concern worldwide (Jackson 2021). In earth's atmosphere, some gases that are present in the earth's atmosphere act like the glass in a greenhouse. These gases tend to trap solar heat thereby preventing it from going back to space (Riechle, 2019). Greenhouse gases in the atmosphere absorbs heat radiation (Riechle, 2019). Though many of these gases occur naturally in earth's atmosphere in a non-harmful quantity, various human activities however, have over time continued to increase the level and concentration of some of them in earth's atmosphere (Table 1). These increases in the concentrations of some of them in the atmosphere has reached a magnitude that is causing great concern globally.

Table 1: Different global GHG emitted by various sectors annually

\begin{tabular}{lc}
\hline Factors that contribute to climate change & Values of GHG emitted (\%) \\
\hline Energy & 73.2 \\
Industry & 5.2 \\
Agriculture, Forest and Land use & 18.4 \\
Waste & 3.2 \\
\hline
\end{tabular}

Source: Ritchie (2020)

According to Steinfeld et al. (2006), three common GHGs that are responsible for climate change occurrence are, Carbon dioxide $\left(\mathrm{CO}_{2}\right)$, Methane and Nitrous oxide. As reported by the European Commission (2020), carbon dioxide $\left(\mathrm{CO}_{2}\right)$ is a greenhouse gas that is most commonly produced by human activities and it accounts for $64 \%$ of man-made global warming. Other greenhouse gases, such as methane and nitrous oxide are usually emitted in smaller quantities, but they tend to trap heat more than $\mathrm{CO}_{2}$. Methane is responsible for $17 \%$ of man-made global warming while nitrous oxide accounts for $6 \%$. Common human or anthropogenic activities that emit GHGs which exacerbates climate change includes as follows:

Burning coal, fumes from industrial machines, oil and gas flaring

These activities produce carbon dioxide and nitrous oxide that exacerbates climate change issues (European Commission, 2020).

\section{Deforestation}

Trees and plants absorb and use $\mathrm{CO}_{2}$ during photosynthesis to produce its food. These trees help to regulate the climate through its ability to absorb $\mathrm{CO}_{2}$ from the atmosphere. So, when they are cut down, the benefit those tree provide by absorbing $\mathrm{CO}_{2}$ which is a greenhouse gas is forfeited (Marshal, 2020). In addition, the carbon that had been stored by the fallen tree is then released into earth's atmosphere thereby exacerbating the already compromised greenhouse effect (Marshall, 2020).

\section{Increasing livestock farming activities}

Ruminant animals particularly, cows and sheep produce large amounts of methane during the process of food digestion. The results in the emission of significant greenhouse gasses that results in climate change challenges in Nigeria and other parts of the world (Oyeagu et al., 2015).

\section{Use of Fertilizers containing nitrogen}

In crop production, the use of fertilizer containing nitrogen to enhance soil fertility tends to increase nitrous oxide emissions from the soil to the atmosphere (Signor and Cerii, 2013).

\section{Effect of climate change globally}

According to Karl and Trenberth (2003), it 


\section{Ahiwe, Obikaonu, Kadurnmba, Iwuji, Emenalom and Etuk}

has been predicted that various long-term effects that will come with exacerbated climate change will include a decrease in sea. Other effects includes an increase in heat waves and heavy precipitation, decreased water resources availability in semi-arid regions as well as increase in frequency and magnitude of extreme events such as heat waves, severe droughts and frequent coastal floods). Expand on this, with a slant on animal agriculture and employment generation in the agro allied sector.

\section{Climate change in Nigeria and its effect}

Estimates as reported by Daggash (2018) shows that Nigeria is responsible for a GHG emission rate of about 490 metric tonnes $\left(\mathrm{CO}_{2}\right.$ equivalent) yearly. Various sectors contributes to the total GHG emission produced in Nigeria (Daggash. 2018; Climatelink, 2019). It is important to note that the GHG emission rate from Nigeria is around $1 \%$ of the world's GHG production (Climatelink, 2019). However, there is increasing concern that as a result of increased numbers of livestock, increased industrialization, high population growth rate as well as a corresponding increase in per capita energy may lead to an increase in climate change challenge in Nigeria in future (Daggash, 2018; Ilevbare, 2019).

According to Suleiman and Abdul-Rahim, (2018), some of the signs of the occurrence of climate change in Nigeria includes: Rising temperatures due to increasing greenhouse gases trapping more heat in the atmosphere; Longer and more extreme droughts in some parts of country (near the northern deserts); Rising sea and water levels threatening coastal communities and estuarine ecosystems. Furthermore, since the 80 's till date, the country has witnessed increased duration and intensity of rainfall that often results in flooding and increased run-off sand erosions especially in the southern, western and eastern part of the country (Yahya, 2019; Institute of
Development Studies, 2020).

Interrelationship of climate change and animal production

Climate change and animal production are negatively interrelated. According to Enete and Amusa, (2010) and Rojas-Downing et al., (2017), climate change negatively affects animal production by increasing heat stress, drought, disease conditions and mortality rate. On the other hand, animal production has been reported to increase the emission of GHGs $\left(\mathrm{CH}_{4}, \mathrm{NO}_{2}\right.$ and $\left.\mathrm{CO}_{2}\right)$, which exacerbates the occurrence of climate change (Parvatha, 2014).

\section{Contribution of farm animals to climate change}

The animal agriculture sector accounts for approximately $15-18 \%$ of the total global greenhouse gas $(\mathrm{GHG})$ emissions resulting from human activities (Garnet, 2009; Gerber et al., 2013; Sejian, 2016). In most aspects of animal agriculture such as meat, egg, and milk production, climate changing gases are continuously released into the atmosphere globally. These gases that are released into earth's atmosphere have the potentials of disrupting weather, temperature and the general ecosystem health. Globally, as the number of farm animals continue to increase, so also does the GHG emissions (Grossi, et al., 2019). On a global scale, cattle rearing has been reported to generate more GHGs, inform of carbon dioxide $\left(\mathrm{CO}_{2}\right)$ than the transportation sector (United Nation News, 2006). It becomes important therefore, that various countries should urgently take adequate steps to implement changes in the current animal agriculture practices to reduce GHGs from the sector.

\section{Effect of climate change on animals}

There are substantialreasons to show that animals are adversely affected by climate change and global warming (Bernabucci, 2019; Lecetara, 2019). Climate change has led to severe increase in temperature and drought with a resultant increase in 


\section{Climate change and youth unemployment challenges in Nigeria}

incidences of heat stress and dehydration in animals (Bernabucci, 2019; Lecetara, 2019). Based on these, the European Union (2018) posits that there is need for, urgent action to help reduce greenhouse gas emissions to prevent climate change that could cause an extinction of some animal and plant species in the nearest future (European Union, 2018).

Below are some aspects of animal production that is affected by climate change:

\section{Decrease in animal performance}

Climate change increases incidents of high temperature that often results in heat stress of animals. Homeothermic animals tends to respond to high temperatures by increasing their heat loss and reducing heat production in their attempt to prevent elevated body temperature (hyperthermia). Such responses include an increase in respiratory and a decrease in feed intake that negatively affect animal overall performance (Elijah and Adedapo, 2006; Henry et al., 2012).

\section{Animal health}

According to Gaughan et al., 2009, Climate change causes severe increase in temperature and heat waves with high intensity and frequency. These severe increase in temperature and heat waves as a result of climate change results in heat stress in animals. Depending on the duration and intensity of the heat stress, livestock may be affected negatively. The negative effect caused by heat stress includes weakness, dizziness, falling sick easily, inability to breath and instant death without notice in most cases.

\section{Immune suppression}

Several factors may affect the proper functioning of the immune system and one of them is heat stress (Lacetera, 2012, $\underline{2019}$ ). Heat stress may impair the function of the immune system in food-producing animals resulting in the occurrence of infections which affects overall production efficiency of an animal.

\section{Death}

In their studies, Dechow and Goodling, 2008; Rojas-Downing et al., 2017 both reported that animals are more prone to heat stress that results in death during very hot periods of the year. In the same vein, both Hahn et al., 2002; Vitali et al., 2015 also explained that there is high mortality rate during period of severe weather condition.

\section{Youth unemployment in Nigeria}

Youths are young people within the age range of 18-34 years (National Youth Policy, 2009). In Nigeria most people within this age bracket that are willing, qualified and able to work but are not gainfully employed and are therefore regarded as unemployed youths. Gbosi (2006) defined unemployment as a situation where people that are willing and able to work at a specified wage or salary are unable to get jobs. According to records from National Bureau of Statistics (2020), Nigeria's youth population qualified to work is about 40 million. Out of this 40 million a total of 11.2 million are unemployed. This value is significant and worrisome. Furthermore, as shown in Table 2 , the rate of unemployment in Nigeria has been on the rise for the past 10 years especially from 2016 to 2020 . For instance, in 2019, the estimated youth unemployment rate in Nigeria was $13.96 \%$ compared to $14.17 \%$ obtained in 2020 (National Bureau of Statistics, 2020; Statista, 2021). With a steady increase in Nigeria's youth population and a corresponding increase in youth unemployment rate over the years, the future is worrisome indeed (Statista, 2021).

A situation where able-bodied youths are not gainfully employed in Nigeria will surely lead to an increase in various societal vices such as armed robbery, cyber-crime, militancy, prostitution, kidnapping and other unwanted vices (Adawo and Atan, 2013). In order to avoid these issues in the 
future, there is the need to create more job opportunities through training and empowerment of entrepreneur minded youths in eco-friendly businesses. The aim of such empowerment scheme should focus on producing youth entrepreneurs that will become job providers and not job seekers. In addition, such Nigerian youth empowerment scheme should be in areas that are eco-friendly to avoid exacerbating climate change issues that is also threatening sustainable existence and utilization of available resources.

Table 2: Youth unemployment rate in Nigeria ( 2010-2020)

\begin{tabular}{lc}
\hline Year & Unemployment \\
\hline 2010 & Rate $(\%)$ \\
2011 & 9.47 \\
2012 & 9.56 \\
2013 & 9.71 \\
2014 & 9.84 \\
2015 & 8.41 \\
2016 & 7.81 \\
2017 & 12.48 \\
2018 & 13.96 \\
2019 & 13.72 \\
2020 & 13.96 \\
\hline
\end{tabular}

Sources: Statista, 2021

The choice of poultry production to reduce climate change and youth unemployment

With the Nigerian youth population and unemployment increase every year, the possibility for the providing opportunities for jobs and means of livelihoods is becoming more difficult. Hence, the need for government and development partners to proactively focus on educating and empowering the Nigerian youths in various eco-friendly entrepreneurship schemes will improve their income and ensure sustainable livelihoods. According to Ile and Baodu, (2018) and UNDP, (2020), one of the interests and actions of any proactive government and the educational sector should be the training and empowerment of youths that will be job creators and not job seekers. With the Nigerian population on the increase and the demand for animal protein source also on the increase yearly (FAO, 2019; Statista, 2021), there is still enough untapped opportunity in the animal agriculture sector. Therefore, the Nigerian Livestock sector can provide the muchneeded empowerment and entrepreneurship option that will not only provide jobs for the Nigerian youth but will also make them job creators.

Irrespective of the fact that farm animal production business can help in youth empowerment in Nigeria, the animal production sector is among the sectors that have been suggested to contribute to GHG emission that results in climate change challenges (FAO, 2006; Wikipedia, 2021). However, some livestock or farm animal are less implicated in substantial and significant emission GHGs. It becomes important therefore, to channel any youth empowerment and entrepreneurship drive to these livestock species that emits lesser GHGs. One such farm animal species is the poultry. Poultry production has the lowest GHGs emission among other farm animals (Monteny et al., 2001; MacLeod et al., 2013). With adequate rearing practice and 


\section{Climate change and youth unemployment challenges in Nigeria}

waste management strategies, the GHG value can be further reduced. Even at the present level of emission, poultry business can be said to be the farm animal production venture of choice in empowering or grooming Nigerian youths to become job creators. In addition to the low level of GHGs emitted by poultry, Price (2019), poultry business is one of the most sorted for among other animal production business. This as explained by the author is because, poultry production gives fast rate of return and ensures profit maximization at least cost if well managed. Furthermore, Poultry products (i.e, live birds, eggs, etc.) commands high market price which can increase the income and improve the livelihood of anyone engaged in this lucrative business venture (Hilmi et al., 2011; Ahiwe et al., 2015). Poultry production can be done on small scale basis or on a large commercial scale, thus, making it suitable for empowering Nigerian youths who can start small and grow big in future. To be candid, there are some shortcomings such as high cost of feed material, building material etc. On a brighter note, these shortcomings can be resolved through adequate government intervention policies (price monitoring and subsidies) as well as providing grants awards to deserving youth. This gesture from the government will make poultry business even more attractive while we help preserve our ecosystem.

Different aspects of poultry production with low GHG emission potentials that youths can be empowered

As explained in the preceding section, unlike other livestock as well as other industrial sectors, poultry production and the products derived from the poultry business produces low GHG emission, thus having low contribution to climate change challenge (Mengesha, 2011). Apart from the rearing and selling of live birds (broilers, layers, turkey, duck, quail etc.), there are other lucrative poultry related ecofriendly opportunities which the government and other stake-holders can channel their empowerment programs at. These alternative poultry related ventures according to; Simonič et al., 2015; Alhotan, 2016; Nwandu et al., 2016; Panda et al., 2016; Nordhagen and Klemm, 2018; Donadeu et al. 2019 include:

Selling of dressed or frozen chicken parts; Sales of Poultry eggs; Marketing of poultry feeds; Selling of poultry medication and vaccines; Hatchery operations and selling of day old chicks; Selling of point of lay birds; Sales of poultry manure (fecal waste/dropping); Transportation of poultry products; Poultry Marketing Agencies; Poultry consulting firm.

\section{Conclusion}

There is an overwhelming indication that livestock production is a major source of GHG emission which invariably results to climate change. Yet, livestock production is an important source of food and employment. The sector also contributes the GDP of Nigeria. Thus, there is need to focus more on farm animals such as poultry that emits less GHG that increases climate change patterns and also provide more jobs for the teeming Nigerian youths. Poultry production comes first to mind in this respect.

\section{Recommendation}

Since the GHG emission from poultry is lower than those of other livestock, yields fast return on investment and a profitable means of livelihood, Government and other concerned stakeholders should ensure that more Nigerian youths are educated and trained in poultry production; Various government agencies, banks, private sectors, civil society, rural co-operative societies, youth agencies in Nigeria with the assistance of various international donor agencies and other stake holder should get 
involved in encouraging youth to embrace poultry production. This they can do by providing grants, soft loans, and organizing grass root training centers in different states of the federation; Creating more awareness among Nigerians about the effects of climate change and how to curb it through:

Substantially reduction of carbon pollution to avoid the worst consequences of climate change.

Combat forest destruction and protect wildlife that live there.

Engage more in businesses that will emit less GHG.

Government should create suitable climate change mitigation policies and ensure that the Nigerian public (especially the youths) are aware of the need to be climate change conscious.

\section{References}

Adawo, M. A. and Atan, J. A. 2013. Graduate Unemployment in Nigeria: Entrepreneurship and Venture Capital Nexus. Journal of Economic and Sustainable Development, 4(9), 75-81.

Ahiwe, E. U., Okere, P. C., Egenuka, F. C., O b i k a o n u, H. O ., Kadurumba, O. E., Ekeledo, P. O., Okehie, U. N. 2015. Involvement of women in poultry production: A veritable way of poverty reduction in Nigerian. Int'1 Journal of Agric. and Rural Development. 18 (2): 2192 - 2202.

Alhotan, R. A. 2016. Strategies To Improve Poultry Feed Formulation For Maximum Performance and Profitability. Available at: https://getd.libs.uga.edu/pdfs/alhot an_rashed_a_201608_phd.pdf. Accessed 16 th January 2021.

Australian Academy of Science. 2021. What is climate change $\square$

Berardelli, J. 2019. How climate change is making hurricanes more dangerous. Yale climate connection.https://yaleclimatecon nections.org/2019/07/how climate-change-is-makinghurricanes-more-dangerous/. Accessed $5^{\text {th }}$ February 2019.

Bernabucci, U. 2019. Climate change: impact on livestock and how can we adapt, Animal Frontiers, 9 (1): 3-5.

Boko, M., Niang, I., and Nyong, A. 2007. Africa. In: Parry M.L, Canziani O.F., Palutikof J.P., van der Linden, P.J., and Hanson, C.E. (eds.), Climatechange: impacts, adaptation, and vulnerability. Contribution of Working Group II to the Fourth Assessment Report of the Intergovernmental Panel on Climate Change (Cambridge, United Kingdom: Cambridge University Press, p. 435).

Climatelink, 2019. Greenhouse Gas Emissions Factsheet: Nigeria.. Accessed $18^{\text {th }}$ January 18, 2021.

Cook, B. 2018. Climate change already making drought worse. Carbon b $\quad r \quad$ i $\quad$ e $\quad f$. https://www.carbonbrief.org/guest -post-climate-change-is-alreadymaking-droughts-worse. Accessed on $5^{\text {th }}$ February, 2021.

Costa, N. D., 2009. Climate change: Implications for water utilization in animal agriculture and poultry, in particular. Proceedings of the 20th Annual Australian Poultry Science Symposium, February 9-11, 2009, University of Sydney, Australia.

Daggash, H. 2018. Nigeria and climate change: Global change and local $\mathrm{c} h$ a 1 l e $\mathrm{n}$ g e $\mathrm{s}$. https://republic.com.ng/junejuly2018/nigeria-climate-change/. Accessed on $19^{\text {th }}$ January 2021.

Donadeu, M., Nwankpa, N., AbelaRidder, B., and Dungu, B. 2019. 
Strategies to increase adoption of animal vaccines by smallholder farmers with focus on neglected diseases and marginalized populations. PLOS Neglected Tropical Diseases $13(3)$ : e 0007279 . Available at: https://doi.org/10.1371/journal.pnt d.0007279. Accessed 16th January 2021.

Elijah, O. A. and Adedapo, A. 2006. The effect of climate on poultry productivity in Ilorin Kwara State Nigeria. International Journal of Poultry Science, 5: 1061-1068.

Enete, A. A. and Amusa, T. A. 2010. Challenges of Agricultural Adaptation to Climate Change in Nigeria: a Synthesis from the Literature. Field Actions Science $R e p o r t s \quad$ [ O n 1 i n e ]. http://journals.openedition.org/fac tsreports $/ 678$. Accessed on $20^{\text {th }}$ January 2021.

Etebong, P. C. 2018. Demography in Nigeria: Problems and Prospects. Biostatistics and Biometrics Open Access Journal. 5(1): 25-30.

European Union. 2018. Our climate, our future: Fighting climate change $\begin{array}{lllllllllll} & o & g & e & t & h & e & r\end{array}$ https://ec.europa.eu/clima/sites/cli ma/files/youth/docs/youth magazi ne en.pdf. Accessed on 18th January 2021

European Commission 2020. Causes of $\mathrm{C} 1 \mathrm{i} \mathrm{m}$ a $\mathrm{te} \mathrm{Ch}$ a $\mathrm{nge}$. https://ec.europa.eu/clima/change/ causes en. Accessed on $19^{\text {th }}$ January 2021.

FAO, 2006. Livestock and Major threat to the environment: remedies urgently needed. FAO Rome Available: http;//www.fao.org/newsroom/en/ news/2006/10000448/index.html. Accessed $16^{\text {th }}$ January 2021.

FAO, 2019. The future of livestock in
Nigeria: Opportunities and challenges in the face of uncertainty. African sustainable livestock 2050. FAO Rome Pg:160 . A v a i 1 a b 1 e a t h t t p:// w w w.fa o.org/3 /ca5464en/ca5464en.pdf. Accessed on $6^{\text {th }}$ February 2021.

FAO, 2020. The Contribution of Agriculture to Greenhouse Gas Emissions. Statistics.. Accessed $5^{\text {th }}$ February, 2021.

Garnett, T. 2009. Livestock-related greenhouse gas emission: Impacts and option for policy makers. Environmental Science Policy, $\begin{array}{llllllllll} & 2 & : & 4 & 9 & 1 & - & 5 & 0 & 3\end{array}$. (12) (PDF) Greenhouse Gas Emission of Broiler Chicken Production in Malaysia using Life Cycle Assessment Guidelines: A Case Study. Available from: https://www.researchgate.net /publication/326077341 Greenho use Gas Emission of Broiler C hicken_Production_in_Malaysia using_Life_Cycle_Assessment_ $\bar{G}$ uideline s_A_Case_Study. Accessed $19^{\text {th }}$ January $202 \overline{1}$.

Gaughan, J. B., N. Lacetera, S. E. Valtorta, H. H. Khalifa, G. L. Hahn, and T. L. Mader. 2009. Response of domestic animals to climate challenges. In: Ebi, K.L., I. Burton, and G.R. McGregor, editors, Biometeorology for adaptation to climate variability and change. Heidelberg (Germany): Springer-Verlag. 131-170.

Gbosi, A. N. 2006. Modern labour economics and policy analysis. Abakaliki, Pack Publishers.

Gerber, P. J. Steinfield, , H., Henderson, B. Mottet, A., Opia, C. Dijkman, J., Falcucci, A. and Tempio, G. 2013. Tackling climate change 
through livestock: A global Assessment of emission and mitigation opportunities. FAO. Rome.

Grossi, G., Goglio, P. Vitali, A. and Williams, A. 2019. Livestock and climate change: impact of livestock on climate and mitigation strategies. Animal Frontier, 9(1):69-76.

Hahn, G. L., T. L. Mader, T. L., Harrington, J. A., Nienaber, J. A. and Frank, K.L. 2002. Living with climatic variability and potential global change: climatological analyses of impacts on livestock performance. Proceeding of the 16th International Congress on Biometeorology, Kansas City (MO).p. 45-49.

Henry, B., Chamley, E., Eckard, R., Guaghan, J. B., and Hagarty, R. 2012. Livestock production in a changing climate: adaptation and mitigation research in Australia. Crop Pasture Science, 63: 191-202.

Hilmi, M., Dolberg, F. and Clarke, B. 2011. Products and profits from poultry. Diversification booklet number 3 Second edition. Rural Infrastructure and Agro-Industries Division Food and Agriculture Organization of the United Nations Rome 2011.

Ile, I. and Boadu, E. S. 2018. The paradox of youth empowerment: Exploring youth intervention programme in Ghana. Cogent Social Sciences (2018), 4: 1528709. Politics and International Relations. Available a $\mathrm{t}$ https://doi.org/10.1080/23311886. 2018.1528709. Accessed on $16^{\text {th }}$ January 2021.

Ilevbare, F. M. 2019. Investigating Effects of Climate Change on Health Risks in Nigeria, Environmental Factors
Affecting Human Health, Ivan $\mathrm{U} h$ e r, I $\mathrm{ntechO}$ pe $\mathrm{n}$, DOI:10.5772/intechopen.86912.A vailablefrom:https://www.intecho pen.com/books/environmentalfactors-affecting-humanhealth/investigating-effects-ofclimate-change-on-health-risks-innigeria.

Institute of Development Studies. 2020. Climate change in Nigeria: Impacts and response. https: available at:preventionweb.net. Accessed $5^{\text {th }}$ February, 2021.

Isserman, K. 1992. Territorial, continental and global aspects of C, N, P and S emissions from agricultural ecosystems. In NATO Advanced Res. Workshop (ARW) on Interactions of $\mathrm{C}, \mathrm{N}, \mathrm{P}$ and $\mathrm{S}$ Biochemical cycles, SpringerVerlag, Heidelberg.

Jackson, S. T. 2021. "Climate change". Encyclopedia Britannica, https://www.britannica.com /science/climate-change. Accessed 5 February 2021.

Karl, T. R. and Trenberth, K. E. 2003. Modern Global Climate Change. Science, 302: 1719-1723.

Lacetera, N. 2012. Effect of environment on immune functions. In: Collier, R.J., and J.L. Collier, editors, Environmental physiology of livestock. Chichester (England): Wiley-Blackwell; p. 165-179.

Lacetera, N. 2019. Impact of climate change on animal health and welfare. Animal Frontiers. 9(1): 26-31.

MacLeod, M., Gerber, P., Mottet, A., Tempio, G., Falcucci, A., Opio, C., Vellinga, T., Henderson, B. and Steinfeld, H. 2013. Greenhouse gas emissions from pig and chicken supply chains - A global life cycle assessment. Food 
and Agriculture Organization of the United Nations (FAO), Rome.

Marshall, M. 2020. Plamting trees doesn't always help with climate change. https://www.bbc.com/future/articl e/20200521-planting-trees-doesntalways-help-with-climate-change. Accessed on $5^{\text {th }}$ February 2021.

Mengesha, M. 2011. Climate Change and the Preference of Rearing Poultry for the Demands of Protein Foods. Asian Journal of Poultry Science, 5: 135-143.

Monteny, G. J., Groenestein, C. M., Hilhorst, M. A., 2001. Interactions and coupling between emissions of methane and nitrous oxide from animal husbandry. Nutrient Cycling Agroecosystems, 60, 123-132.

National Bureau of Statistics. 2020. National Unemployment Rates. . Accessed on $22^{\text {nd }}$ Janaury 2021.

Nordhagen, S., and Klemm, R. 2018. Implementing small-scale poultry-for-nutrition projects: Successes and lessons learned Maternal and Child Nutrition Volume 14, Issue S3 Supplement: Eggs: A High Potential Food for Improving Maternal and Child Nutrition October 2018 e12676. A v a i 1 a b 1 e a t : https://doi.org/10.1111/mcn.12676 . Accessed $19^{\text {th }}$ January 2021.

Nwandu, P. I., Ojogbane, J. A., Okoh, C., and Okechukwu, F. 2016. Poultry Production Business: A Means of Alleviating Poverty among Farmers. International Journal of Innovative Agriculture \& Biology Research 4(2):21-30, April-June, 2016 ISSN: 2354-2934. Available at: https://seahipaj.org/journalsci/june-2016/IJIABR/full/IJIABRJ-3-2016.pdf. Accessed 18th January 2021.
National Youth Policy. 2009. Second National Youth Policy Document of the Federal Republic of Nigeria $\begin{array}{llll}2 & 0 & 0 & 9\end{array}$ https://www.youthpolicy.org/natio nal/Nigeria_2009_National_Youth Policy.pdf. Accessed on 20th January, 2021.

Onuba, I. 2020. Tackling unemployment through industrial skills programme. Published February 16,2020 . https://punchng.com/tacklingunemploment-through-industrialskills-programme/ Accessed $5^{\text {th }}$ February 2021.

Onyeagu, C. E., Akpa, M. O., and Ani, A. O. 2015. The Contribution of Ruminant Animals to Climate Change and its Mitigation Strategies. In: Natural Ecosystem and Climate Change. Dr. Pawan Kumar 'Bharti' and Dr. Khwairakpam Gajananda. (Editors). Discovery Publishing House PVT. Ltd. 4383/4B, Ansari Road, Darya Ganj New Delhi-110002 (India). Pp 71-86.

Panda, A. K., Kumar, A., Sahoo, B., Tanuja, S., and Swain, B. K. (eds.) 2016. Low Cost Feed Formulation for Rural Poultry Production. In book: Empowering Farmwomen through Livestock and Poultry Intervention. ICARCentral Institute for Women in Agriculture. Available at: https://www.researchgate.net/publi cation/316667141_Low_Cost_Fee d_Formulation_for_Rural_Poultry Production. Accessed 19th January 2021.

Price, R. 2019. Youth employment needs in Nigeria. Institute of Development Studies. Knowledge, evidence and learning for development (K4D). A v a i l a ble a t : 
https://assets.publishing.service.go $\mathrm{v} \cdot \mathrm{u} \quad \mathrm{k} / \mathrm{l}$ e/691 Youth Employment in Ni geria.pdf. Accessed $16^{\text {th }}-\overline{\text { January }}$ 2021.

Reichle, D. E. 2019. The global carbon cycle and climate change: Scaling Ecological Energetics from Organism to the Biosphere. 1st Edition. 362 Pp.

Ritchie, H. 2020. Sector by sector: where do global greenhouse gas emission c o m e $\quad$ f $\mathrm{r} \mathrm{o} \mathrm{m}$ https://ourworldindata.org/ghgemissions-by-sector\#licence. Accessed on $19^{\text {th }}$ January, 2021.

Rojas-Downing, M. M. Nejadhashemi, A. P., Harrigan, T. and Woznick, S. A. 2017. Climate change and livestock: Impacts, adaptation, and mitigation. Climate Risk Management. 16: 145-163.

Sejian, V., Bhatta, R., Malik, P. K., Madiajagan, B., Saif Al-Hosni, Y. A., Sullivan, M. and Gaughan, J. B. 2016. Livestock as Sources of Greenhouse Gases and Its Significance to Climate Change, Greenhouse Gases, Bernardo Llamas Moya and Juan Pous, IntechOpen, DOI: 10.5772/62135. A v a i 1 a b 1 e f r o m : https://www.intechopen.com/book s/greenhouse-gases/livestock-assources-of-greenhouse-gases-andits-significance-to-climate-change.

Shiru, M. S. Shahid, S., Dewan, A., Chung, E., Alias, N., Ahmed, K. and Hassan, Q. K. 2020. Projection of metrological droughts in Nigeria during growing seasons under climate change scenario. Science Report. 10:10107.

Signor, D. and Cerri, C. E. P. 2013. Nitrous oxide emissions in a gricultural soils: a review.Pesquisa Agropecuária Tropical, Goiânia. 43 (3): 322-338. Simonič, M., Dumičić, K., and Žmuk, B. 2015. Developing Marketing Strategy of Poultry Meat Supply in Eu 28 Countries: Multivariate Analysis Approach. Review of Innovation and Competitiveness

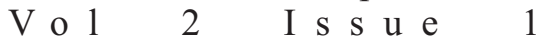
https://www.researchgate.net/publi cation Accessed $17^{\text {th }}$ January 2021.

Statista, 2021. Nigeria: Youth unemployment rate from 1999 to 2020 . A v a i 1 a b 1 e a t https://www.statista.com/statistics/ 812300/youth-unemploymentrate-in-nigeria/. Accessed $18^{\text {th }}$ January 2021.

Steinfeld, H. Gerber P., Wassenaar, T., Castel V., Rosales, M., and de Haan, C. 2006. Livestock's Long Shadow: Environmental Issues and Options. Rome: food and Agricultural Organization of the United Nations.

Sulaiman, C. and Abdul-Rahim, A.S. 2018.Population Growth and $\mathrm{CO}_{2}$ Emission in Nigeria: $\mathrm{A}$ Recursive ARDL Approach. Sage J o u r n a l . 1 - 14 . D O I : $10.1177 / 2158244018765916$

Trenberth, K. V. 2018. Climate change caused by human activities is happening and it already has major consequences. Journal of Energy and Natural Resources Law. Pp 1-6. DOI:10.1080/02646811.2018.145 0895.

United Nation News 2006. Rearing cattle produces more greenhouse gases than driving cars, UN report $\begin{array}{llllll}\mathbf{w} & \mathbf{a} & \mathbf{r} & \mathbf{n} & \mathbf{s} & \text {. }\end{array}$ https://news.un.org/en/story/2006/ $11 / 201222$-rearing-cattleproduces-more-greenhouse-gasesdriving-cars-un-report-warns. 
Accessed $18^{\text {th }}$ January 18, 2021.

United Nations Development Programme - UNDP. 2020. Youth Empowerment. Available at: https://www.undp.org/content/und $\mathrm{p} / \mathrm{en} /$ home/ourwork/democraticg o v e r n a n c e - a n d p e a c e build ing / y o u th empowerment/. Accessed on the 17th January 2021.

Vitali, A., Felici, A., Esposito, S., Bernabucci, U., Bertocchi, L., Maresca, C., Nardone, A. and Lacetera. N. 2015. The impact of heat waves on dairy cow mortality. Journal of Dairy Science, 98:4572-4579.
Wikipedia. 2021. Climate change and $\begin{array}{lllllllllllllllll}A & g & r & i & c & u & l & t & u & r & e\end{array}$. https://en.wikipedia.org/wiki/Clim ate change and agriculture. Accessed on $20^{\overline{\text { th }}}$ January 2021.

Worldmeter. 2021. Nigeria population. https:/www.worldometers.info/w orld-population/nigeriapopulation/

Yahya, M. 2019. Nigeria lead on climate change. UNDP, Nigeria. https://www.undp.org/ content/undp/en/home /blog/2019/nigeria-must-lead-onclimate-change.html.

Received: $28^{\text {th }}$ October, 2020 Accepted: $5^{\text {th }}$ January, 2021 